\title{
КОМПЛЕКСНА ОЦІНКА УСПІШНОСТІ ЛІКАРІВ-ІНТЕРНІВ ЗА РЕЗУЛЬТАТАМИ ДЕРЖАВНОЇ АТЕСТАЦІї
}

\author{
Львівський національний медичний університет імені Данила Галицького, \\ м. Львів, Україна
}

\begin{abstract}
Мета: покращити якість фрахової підготовки здобувачів вищої медичної освіти на основі комплексного аналізу їхньої успішності.

Матеріали і методи. Дослідження проводили серед здобувачів, які навчались в інтернатурі Львівського національного медичного університету імені Данила Галицького та проходили заключну державну атестацію у період 2011-2017 рр. за такими критеріями: результати складання ліцензійних тестових іспитів «Крок-1», «Крок-2», «Крок-З», складання державних іспитів та результат заключної атестації. Використано статистичні методи, структурно-логічний аналіз та системний підхід.

Результати. За результатами складання ліцензійного іспиту «Крок-1» протягом 2011-2017 рр. зафріксовано зростання середнього бала для спеціальності «Медицина невідкладних станів» та «Загальна практика - сімейна медицина». Спостерігали тенденцію до зростання середнього результату проходження іспитів «Крок-2» та «Крок-3» та середньої оцінки складання державних іспитів для здобувачів усіх лікарських спеціальностей. Найнижчу середню оцінку заключної атестації протягом 2011-2017 рр. констатовано у здобувачів зі спеціальності «Стоматологія».

Висновки. Дослідження результатів успішності здобувачів вищої медичної освіти на додипломному та післядипломному рівнях дозволить оцінити та покращити якість фрахової підготовки та наблизити її до європейських стандартів.
\end{abstract}

КЛЮчОВІ СЛОВА: здобувачі вищої освіти; ліцензійний тестовий іспит; результат заключної атестації.

У процесі надання медичної освіти невід'ємним індикатором оцінки її якості залишається визначення показників підготовки медичних фрахівців та діагностика їх навчальних результатів [3, 4].

Успішне складання ліцензійного тестового іспиту «Крок-1» визначає якість медичної освіти на додипломному рівні та відповідність державним стандартам вищої освіти [7].

При підготовці до складання іспитів «Крок-2» та «Крок-3» доцільно впроваджувати в навчальний процес дистанційні форми, які довели свою ефективність та слугують інструментом самоконтролю, а також сприяють досягненню більш високих результатів їх складання [5, 6].

Забезпечення належного контролю за рівнем знань і практичних вмінь на додипломному та післядипломному рівнях $€$ необхідною складовою у процесі інтеграції вищої медичної освіти у світовий освітній простір $[1,2]$.

Мета дослідження: провести комплексне дослідження успішності лікарів-інтернів Львівського національного медичного університету імені Данила Галицького впродовж 2011-2017 рр.

Матеріали і методи. Дослідження проводили серед здобувачів, які навчались в інтернатурі Львівського національного медичного університету імені Данила Галицького (далі - лНМУ) та проходили заключну державну атестацію у період (с) О. Є. Січкоріз, 2020
2011-2017 рр. за такими критеріями: результати складання ліцензійних тестових іспитів «Крок-1» (бали), «Крок-2» (бали), «Крок-3» (\%), складання державних іспитів (середня традиційна оцінка) та результат заключної атестації (середня традиційна оцінка). Використано статистичні методи, структурно-логічний аналіз та системний підхід.

Результати дослідження та їх обговорення. За всі роки спостережень здобувачі вищої освіти лНМУ на до- та післядипломному рівнях показали високі результати оцінювання зі значним перевищенням прохідного бала. Так, аналіз результатів ліцензійного тестового іспиту «Крок-1» показав, що при прохідному балі для медичних спеціальностей від 163 до 178 балів у різні роки спостережень, мінімальний середній бал іспиту здобувачами був 198,61 («Загальна практика - сімейна медицина» (далі - «ЗП-СМ»), 2014 р.). Для стоматологів прохідний бал коливався протягом семи років від 166 до 183 балів, а мінімальний середній бал при складанні «Крок-1» був зареєстрований у 2015 р. - 199,88 бала.

Динаміка змін середніх балів ліцензійного іспиту «Крок-1» протягом семи років для кожного фаху мала хвилеподібний характер із певними особливостями. Зокрема, зростання середнього бала спостерігали для спеціальностей «Медицина невідкладних станів» (далі - «МНС») (від 202,75 до 206,36 бала) та «ЗП-СМ» (від 204,20 
до 208,03 бала), незначне зниження - для спеціальностей «Внутрішні хвороби» (від 209,26 до 205,48 бала), «Педіатрія» (від 211,34 до 202,64 бала) та «Стоматологія» (від 211,19 до 201,04 бала).

Прохідний бал ліцензійного тестового іспиту «Крок-2» протягом 2011-2017 рр. був у межах від 97 до 153 бали (для медичних спеціальностей) та від 131 до 164 бали (для стоматологів), що $€$ значно нижче, ніж результати тестування студентів (мінімальний бал - 195,16, спеціаль- ність «Стоматологія», 2012 р.). Аналіз результатів проходження іспиту «Крок-2» студентами ЛНМУ показав зростання балів всіх спеціальностей у ряді 2011-2017 рр. (від 196,75-204,10 в 2011 р. до 203,0-208,68 бала у 2017 р.).

У результаті аналізу динаміки даних ліцензійного тестового іспиту «Крок-3» у розрізі спеціальностей за 2011-2017 рр. встановлено, що при прохідному балі 70,5 \% інтерни лНМУ склали іспит із мінімальним результатом 75,16 \% («3П-СМ» у 2014 р.) (рис. 1).

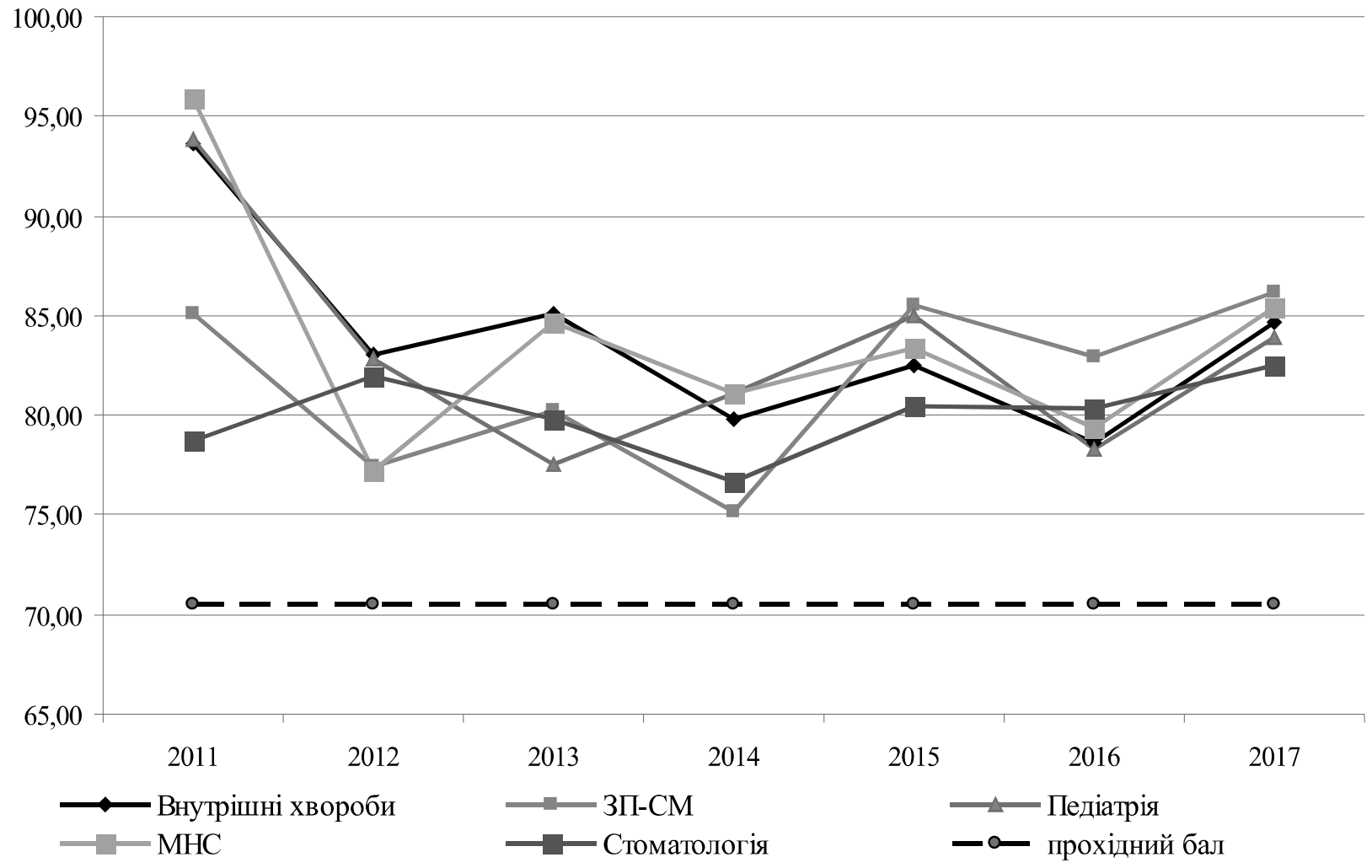

Puc. 1. Динаміка результатів ліцензійного тестового іспиту «Крок-3» (\%) у розрізі спеціальностей 3а 2011-2017 pp.

Середній результат іспиту «Крок-3» у двох спеціальностей протягом семи років має тенденцію до зростання: «Стоматологія» - від 78,72 до 82,48 \%; «ЗП-СМ» - від 85,13 до 86,18 \%; та у трьох - протягом шести (від 2012 до 2017 рр.): «Внутрішні хвороби» - від 83,04 до 84,66 \%; «Педіатрія» - від 82,78 до 83,95 \%; «МНС» - від 77,17 до $85,43 \%$.

Відповідно до даних, наведених у таблиці 1, найкращі результати складання ліцензійного тестового іспиту «Крок-3» серед студентів, які закінчили інтернатуру ЛНМУ в період 2011-2017 рр. та були переведені на навчання з інших закладів вищої освіти (3ВО), продемонстрували студенти Буковинського (БДМУ), Вінницького (ВНМУ), ІваноФранківського (ІФНМУ) університетів, Медичного інституту Сумського державного університету (МІСДУ), Луганського державного медичного уні- верситету (ЛДМУ) та Української медичної стоматологічної академії (УМСА).

Найнижчі результати складання ліцензійного тестового іспиту «Крок-З» спостерігали у студентів Дніпропетровського медичного інституту традиційної і нетрадиційної медицини (ДМІНМ), Запорізького державного медичного університету (ЗДМУ), Львівського медичного інституту (ЛМІ), Київського медичного інституту (КМІ УАНМ) та Ужгородського державного університету (УДУ).

Аналіз динаміки результатів складання державних іспитів у розрізі спеціальностей за 20112017 рр. показав зростання середньої оцінки в здобувачів усіх лікарських спеціальностей та незначне зниження (на $1 \%$ (0,04 бала)) - у майбутніх стоматологів. Середні оцінки здобувачів медичних спеціальностей коливались у межах від 3,87-4,11 в 2011 р. до 4,14-4,21 у 2017 р. 
Таблиця 1. Результати складання студентами ліцензійного тестового іспиту «Крок-3» у період 2011-2017 рр. (поділ за закладами вищої освіти)

\begin{tabular}{|c|c|c|c|c|c|c|c|}
\hline $\begin{array}{c}\text { Заклад вищої } \\
\text { освіти }\end{array}$ & 2011 & 2012 & 2013 & 2014 & 2015 & 2016 & 2017 \\
\hline БДМУ & $\begin{array}{c}93,75 \pm 4,64 \\
(n=12)\end{array}$ & $\begin{array}{c}78,38 \pm 7,17 \\
(n=8)\end{array}$ & $\begin{array}{c}75,75 \pm 5,19 \\
(n=4)\end{array}$ & $\begin{array}{c}72,5 \pm 9,2 \\
(n=7)\end{array}$ & $\begin{array}{c}81,63 \pm 8,15 \\
(n=8)\end{array}$ & $\begin{array}{c}78,04 \pm 7,48 \\
(n=14)\end{array}$ & $\begin{array}{c}84,83 \pm 4,4 \\
(n=15)\end{array}$ \\
\hline BHMY & $\begin{array}{c}84,38 \pm 9,3 \\
(n=4)\end{array}$ & $\begin{array}{c}89,6 \pm 4,48 \\
(n=5)\end{array}$ & $\begin{array}{c}6,75 \pm 11,38 \\
(n=7)\end{array}$ & $\begin{array}{c}83,92 \pm 3,54 \\
(n=6)\end{array}$ & $\begin{array}{c}80,29 \pm 8,96 \\
(n=7)\end{array}$ & $\begin{array}{c}81,5 \pm 5,55 \\
(n=11)\end{array}$ & $\begin{array}{c}87,19 \pm 3,91 \\
(n=8)\end{array}$ \\
\hline ДДМА & $\begin{array}{c}87,00 \pm 5,66 \\
(n=2)\end{array}$ & $\begin{array}{c}86,13 \pm 6,74 \\
(n=4)\end{array}$ & $\begin{array}{c}79,75 \pm 7,63 \\
(n=17)\end{array}$ & $\begin{array}{c}79,75 \pm 8,83 \\
(n=2)\end{array}$ & $\begin{array}{c}78,13 \pm 7,6 \\
(n=4)\end{array}$ & $\begin{array}{c}80,28 \pm 7,57 \\
(n=9)\end{array}$ & $\begin{array}{c}89 \\
(n=1)\end{array}$ \\
\hline ДМІНМ & $\begin{array}{l}63,5 \\
(n=1)\end{array}$ & - & - & - & - & - & - \\
\hline ДНМУ & $\begin{array}{c}88,5 \pm 7,07 \\
(n=2)\end{array}$ & $\begin{array}{c}88 \\
(n=1)\end{array}$ & - & $\begin{array}{c}79 \\
(n=1)\end{array}$ & $\begin{array}{c}76,92 \pm 5,33 \\
(n=6)\end{array}$ & $\begin{array}{l}83,5 \\
(n=1)\end{array}$ & - \\
\hline ЗДМУ & $\begin{array}{l}91,5 \\
(n=1)\end{array}$ & $\begin{array}{c}73 \\
(n=1)\end{array}$ & - & $\begin{array}{c}79,75 \pm 8,83 \\
(n=2)\end{array}$ & - & - & $\begin{array}{c}85,75 \pm 3,89 \\
(n=2)\end{array}$ \\
\hline ІФНМУ & $\begin{array}{c}90,67 \pm 5,57 \\
(n=7)\end{array}$ & $\begin{array}{c}79,25 \pm 10,23 \\
(n=12)\end{array}$ & $\begin{array}{c}77,79 \pm 8,71 \\
(n=16)\end{array}$ & $\begin{array}{c}73,35 \pm 10,11 \\
(n=10)\end{array}$ & $\begin{array}{c}86,2 \pm 6,99 \\
(n=10)\end{array}$ & $\begin{array}{c}77,87 \pm 7,54 \\
(n=21)\end{array}$ & $\begin{array}{c}83,96 \pm 5,7 \\
(n=14)\end{array}$ \\
\hline KMI УAHM & $\begin{array}{c}67 \\
(n=1)\end{array}$ & - & $\begin{array}{c}84 \\
(n=1)\end{array}$ & $\begin{array}{r}74,5 \\
(n=1)\end{array}$ & $\begin{array}{l}60,5 \\
(n=1)\end{array}$ & $\begin{array}{r}77,5 \\
(n=1)\end{array}$ & - \\
\hline $\begin{array}{l}\text { Кримський держав- } \\
\text { ний медичний } \\
\text { університет імені } \\
\text { С. І. Георгієвського }\end{array}$ & - & - & - & - & $\begin{array}{c}74 \pm 10,6 \\
(n=2)\end{array}$ & - & - \\
\hline ЛMI & $\begin{array}{c}74,54 \pm 9,15 \\
(n=49)\end{array}$ & $\begin{array}{c}77,65 \pm 9,5 \\
(\mathrm{n}=44)\end{array}$ & $\begin{array}{c}74,04 \pm 13,22 \\
(n=37)\end{array}$ & $\begin{array}{c}76,29 \pm 10,6 \\
(n=14)\end{array}$ & $\begin{array}{c}75,85 \pm 11,01 \\
(n=10)\end{array}$ & $\begin{array}{c}77,12 \pm 7,67 \\
(n=17)\end{array}$ & $\begin{array}{c}81,31 \pm 6,4 \\
(n=24)\end{array}$ \\
\hline ЛНМУ & $\begin{array}{c}84,73 \pm 10,94 \\
(n=325)\end{array}$ & $\begin{array}{c}82,8 \pm 8,31 \\
(n=272)\end{array}$ & $\begin{array}{c}83,08 \pm 7,73 \\
(n=256)\end{array}$ & $\begin{array}{c}77,72 \pm 10,28 \\
(n=267)\end{array}$ & $\begin{array}{c}83,2 \pm 8,97 \\
(n=290)\end{array}$ & $\begin{array}{c}81,27 \pm 7,1 \\
(n=275)\end{array}$ & $\begin{array}{c}84,19 \pm 4,93 \\
(n=269)\end{array}$ \\
\hline лдМУ & - & - & $\begin{array}{c}87,5 \\
(n=1)\end{array}$ & - & $\begin{array}{l}84,5 \\
(n=1) \\
\end{array}$ & $\begin{array}{c}80 \\
(n=1)\end{array}$ & - \\
\hline HMY & $\begin{array}{c}83,58 \pm 9,99 \\
(n=18)\end{array}$ & $\begin{array}{c}82,61 \pm 6,69 \\
(n=14)\end{array}$ & $\begin{array}{c}78,76 \pm 9,38 \\
(n=25)\end{array}$ & $\begin{array}{c}78,14 \pm 8,88 \\
(n=28)\end{array}$ & $\begin{array}{c}82,33 \pm 9,52 \\
(n=15)\end{array}$ & $\begin{array}{c}78,51 \pm 7,76 \\
(n=21)\end{array}$ & $\begin{array}{c}80,7 \pm 5,86 \\
(n=14)\end{array}$ \\
\hline ОДМУ & $\begin{array}{c}88,83 \pm 7,32 \\
(n=3)\end{array}$ & - & - & - & - & $\begin{array}{c}71,5 \pm 12,02 \\
(n=2)\end{array}$ & $\begin{array}{l}84,5 \\
(n=1) \\
\end{array}$ \\
\hline МІСДУ & $\begin{array}{c}69 \\
(n=1)\end{array}$ & $\begin{array}{l}84,5 \\
(n=1) \\
\end{array}$ & - & - & - & - & $\begin{array}{l}89,5 \\
(n=1)\end{array}$ \\
\hline ТДМУ & $\begin{array}{c}93,67 \pm 5,00 \\
(n=9)\end{array}$ & $\begin{array}{c}80,38 \pm 10,72 \\
(n=20)\end{array}$ & $\begin{array}{c}82,00 \pm 8,92 \\
(n=11)\end{array}$ & $\begin{array}{c}81,14 \pm 6,22 \\
(n=18)\end{array}$ & $\begin{array}{c}79,79 \pm 8,03 \\
(n=18)\end{array}$ & $\begin{array}{c}82,37 \pm 7,96 \\
(n=21)\end{array}$ & $\begin{array}{c}81,55 \pm 6,5 \\
(n=13)\end{array}$ \\
\hline Уду & $\begin{array}{c}88,00 \pm 18,19 \\
(n=3)\end{array}$ & $\begin{array}{l}82,5 \\
(n=1)\end{array}$ & $\begin{array}{c}77,22 \pm 12,88 \\
(n=9)\end{array}$ & $\begin{array}{c}68,5 \pm 8,66 \\
(n=4)\end{array}$ & $\begin{array}{c}82,5 \pm 9,81 \\
(n=6)\end{array}$ & $\begin{array}{c}75,17 \pm 6,05 \\
(n=3)\end{array}$ & $\begin{array}{c}79,75 \pm 6,06 \\
(n=4)\end{array}$ \\
\hline УMCA & $\begin{array}{c}74,29 \pm 11,01 \\
(n=10)\end{array}$ & $\begin{array}{c}82,6 \pm 9,4 \\
(n=10)\end{array}$ & $\begin{array}{c}79,18 \pm 7,48 \\
(n=11)\end{array}$ & $\begin{array}{c}80,92 \pm 8,16 \\
(n=6)\end{array}$ & $\begin{array}{c}73,83 \pm 16,44 \\
(n=3)\end{array}$ & $\begin{array}{c}86,7 \pm 8,17 \\
(n=5)\end{array}$ & $\begin{array}{c}84,5 \pm 5,44 \\
(n=6)\end{array}$ \\
\hline XHMY & - & - & - & - & $\begin{array}{c}81,37 \pm 4,2 \\
(n=3)\end{array}$ & $\begin{array}{c}82,33 \pm 9,54 \\
(n=3)\end{array}$ & $\begin{array}{c}84,5 \pm 6,36 \\
(n=2)\end{array}$ \\
\hline
\end{tabular}

Аналіз результатів заключної атестації (рис. 2) здобувачів вищої освіти ЛНМУ протягом 20112017 рр. показав, що найнижча середня оцінка була у стоматологів: від 3,88 (2011 р.) до 3,91 (2017 р.). Здобувачі медичних спеціальностей отримали значно вищі оцінки заключної атестації: від 4,25-4,71 в 2011 р. до 4,52-4,76 у 2017 р.

\section{Висновки}

За результатами складання ліцензійного іспиту «Крок-1» протягом 2011-2017 рр. зафріксовано зростання середнього бала для спеціальностей «Медицина невідкладних станів» та «Загальна практика - сімейна медицина» та незначне зниження - для спеціальностей «Внутрішні хвороби», «Педіатрія» та «Стоматологія».

Аналізрезультатівпроходженняіспиту «Крок-2» студентами ЛНМУ показав зростання балів всіх спеціальностей впродовж 2011-2017 рр.

Зросла середня оцінка складання державних іспитів у здобувачів всіх лікарських спеціальностей, лише у майбутніх стоматологів зафіксовано незначне її зниження на 1 \% (0,04 бала).

Середній результат іспиту «Крок-З» для спеціальностей «Стоматологія» та «Загальна прак- 


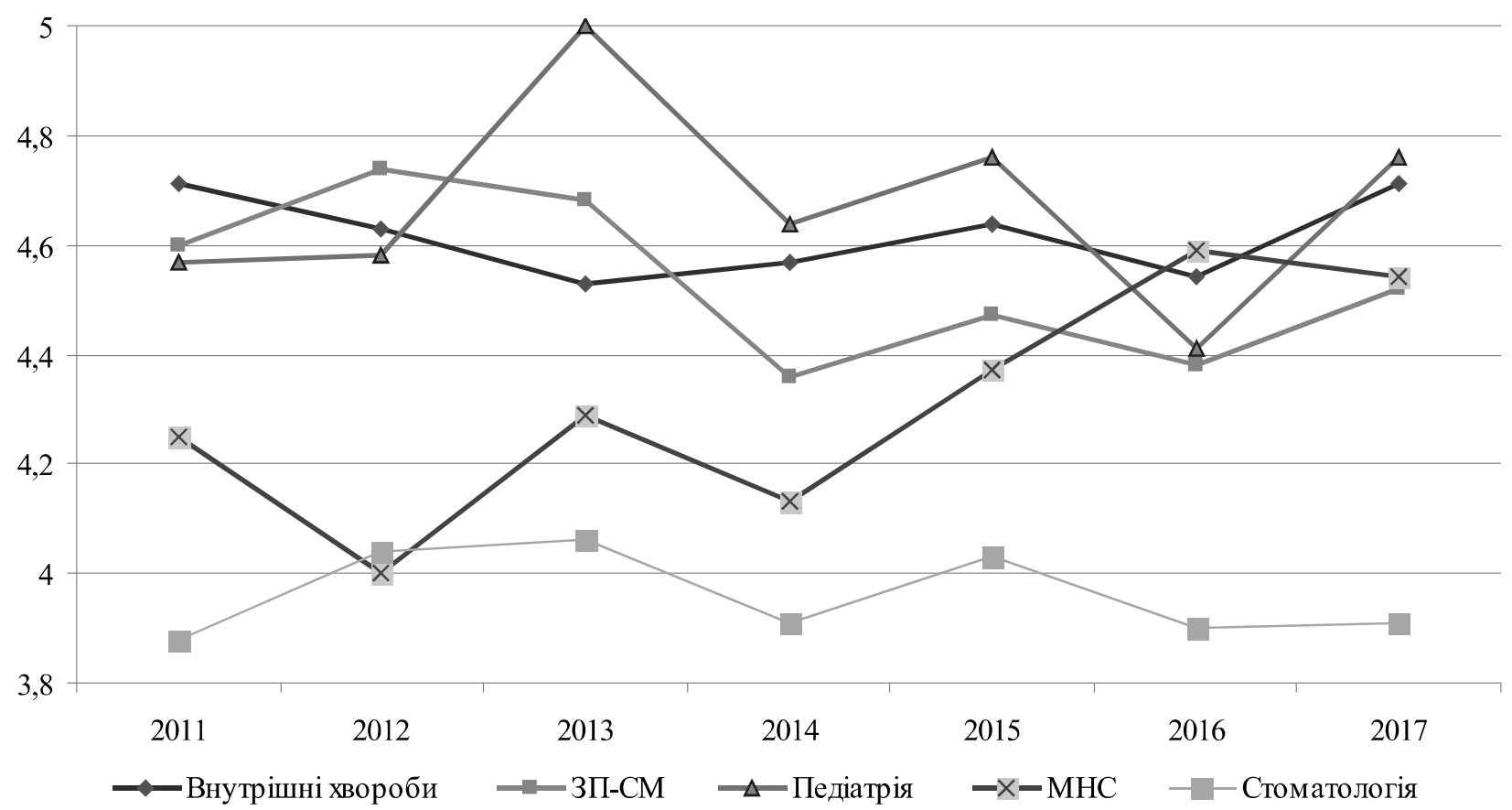

Рис. 2. Динаміка результатів заключної атестації у розрізі спеціальностей за 2011-2017 pp. (середня традиційна оцінка).

тика - сімейна медицина» має тенденцію до зростання протягом семи досліджуваних років. А для спеціальностей «Внутрішні хвороби», «Педіатрія» та «Медицина невідкладних станів» таку ж тенденцію спостерігали з 2012 до 2017 р.

Найнижчу середню оцінку заключної атестації протягом 2011-2017 рр. констатовано для спеціальності «Стоматологія».
Перспективи подальших досліджень пов'язані 3 впровадженням сучасних інноваційних методик у навчальний процес для покращення якості фрахової підготовки здобувачів медичної освіти на до- та післядипломному рівнях підготовки.

\section{Список літератури}

1. Гуменюк О. М. Проблеми контролю знань і вмінь студентів в умовах інтеграції вищої медичної освіти у світовий освітній простір / О. М. Гуменюк // Педагогічний процес: теорія і практика. - 2014. - № 3. - С. 52-54.

2. Гутор Т. Г. Ретроспективні основи процесу становлення та розвитку групового методу експертного оцінювання I

Т. Г. Гутор // Сучасні медичні технології. - 2013. - № 2. - С. 37-39.

3. Зіменковський А. Б. Проблеми і завдання освітньо-професійної підготовки клінічного провізора / А. Б. Зіменковський, Л. Є. Зарума, Р. Б. Лесик, О. Є. Січкоріз // Клінічна фармація, фрармакотерапія та медична стандартизація. 2008. - № 1. - С. 61-65.

4. Зіменковський Б. С. Рейтинг як складова системи управління якістю підготовки лікарів і провізорів / Б. С. Зіменковський, М. Р. Гжегоцький, І. І. Солонинко // Медична освіта. - 2012. - № 2. - С. 49-51.

5. Ортеменка Е. П. Дистанционный контроль теоретической подготовленности студентов-медиков шестого курса к сдаче тестового лицензионного экзамена «Крок 2» / Е. П. Ортеменка // Смоленский медицинский альманах. 2016. - № 2. - С. 129-133.

6. Січкоріз О. Є. Інтеграція дистанційної форми в навчальний процес на післядипломному етапі підготовки лікарівінтернів до складання ліцензійного іспиту «Крок-3. Стоматологія»: реалії та перспективи / О. Є. Січкоріз, Т. І. Пупін, л. Ю. Мінько, Т. С. Колач // Медична освіта. - 2018. - № 2. - С. 125-130.

7. Стандарти вищої освіти [Електронний ресурс]. - Режим доступу : https://mon.gov.ua/ua/osvita/visha-osvita/ naukovo-metodichna-rada-ministerstva-osviti-i-nauki-ukrayini/zatverdzheni-standarti-vishoyi-osviti.

\section{References}

1. Humeniuk, O.M. (2014). Problemy kontroliu znan i vmin studentiv v umovakh intehratsii vyschoi medychnoi osvity u svitovyi osvitnii prostir [Problems of students' knowledge and skills control in higher medical educational establishments in a world space integration period]. Pedahohichnyi protses: teoriia i praktyka - Pedagogical Process: Theory and Practice, 3 , 52-54 [in Ukrainian]. 
2. Hutor, T.H. (2013). Retrospektyvni osnovy protsesu stanovlennia ta rozvytku hrupovoho metodu ekspertnoho otsiniuvannia [Retrospective basis of the formation and development process of the group method of expert evaluation]. Suchasni medychni tekhnolohii - Modern Medical Technologies, 2, 37-39 [in Ukrainian].

3. Zimenkovskyj, A.B., Zaruma, L.Ye., Lesyk, R.B., \& Sichkoriz, O.Ye. (2008). Problemy i zavdannia osvitnio-profesiinoi pidhotovky klinichnoho provizora [Problems and tasks of educational and professional training of a clinical pharmacist]. Klinichna farmatsiia, farmakoterapiia ta medychna standartyzatsiia - Clinical Pharmacy, Pharmacotherapy and Medical Standardization, 1, 61-65 [in Ukrainian].

4. Zimenkovskyj, B.S., Hzhehotskyj, M.R., \& Solonynko, I.I. (2012). Reltynh iak skladova systemy upravlinnia iakistiu pidhotovky likariv i provizoriv [Rating as a constituent of quality management system in medical and pharmaceutical training]. Medychna osvita - Medical Education, 2, 49-51 [in Ukrainian].

5. Ortemenka, E.P. (2016). Dystantsyonnyy kontrol teoretycheskoy podgotovlennosti studentov-medikov shestogo kursa $\mathrm{k}$ sdache testovogo litsenzyonnogo ekzamena «Krok 2» [Distance monitoring of theoretical preparedness of the sixth year medical students to the test licensed exam "Krok 2"]. Smolenskiy medytsynskyy almanakh - Student's Medical Almanac, 2, 129-133 [in Russian].

6. Sichkoriz, O.Ye., Pupin, T.I., Minko, L.Yu., \& Kolach, T.S. (2018). Intehratsiia dystantsiinoi formy v navchalnyi protses na pisliadyplomnomu etapi pidhotovky likariv-interniv do skladannia litsenziinoho ispytu «Krok-3. Stomatolohiia»: realii ta perspektyvy [Integration of the distance e-learning in the educational process at the postgraduate education during preparation to the exam passing of licensed exam "Krok 3. Dentistry": reality and prospects]. Medychna osvita - Medical Education, 2, 125-130 [in Ukrainian].

7. Standarty vyshchoi osvity [Standards of higher education]. Retrieved from: https://mon.gov.ua/ua/osvita/visha-osvita/ naukovo-metodichna-rada-ministerstva-osviti-i-nauki-ukrayini/zatverdzheni-standarti-vishoyi-osviti

\section{THE COMPLEX GAIN SCORE OF INTERNSHIP DOCTORS ACCORDING TO THE RESULTS OF THE STATE ASSESSMENT (ACADEMIC PROGRESS)}

O. Ye. Sichkoriz

Danylo Halytsky Lviv National Medical University, Lviv, Ukraine

Purpose: to improve the professional training of higher education applicants based on the complex analysis of their academic performance.

Materials and Methods. The research was carried out among the applicants who studied in the internship under Danylo Halytsky Lviv National Medical University and had passed the final state attestation within the period of 2011-2017 years regarding the following criteria: the results of passing the licensed test exams "Krok-1", "Krok-2", "Krok-3"; the results of passing the state exams and the results of the final attestation. The statistical methods, structural-and-logical analysis and systemic approach were used.

Results. According to the results of passing the licensed test exam "Krok-1" within the period of 2011-2017, the mean grade growth in specialties "Medicine of urgent conditions" and "General medicine - family medicine" was recorded. There is a tendency of growth of average result in passing the "Krok-2" and "Krok-3" test exams and the mean grade of passing the state exams by applicants of all medical specialties. The lowest mean grade of the final attestation within the period of 2011-2017 was recorded in the applicants of Dentistry specialty.

Conclusions. The research of the results concerning the progress in studies of applicants of higher education at pregraduation and postgraduation levels will make possible to evaluate and improve the quality of professional training of higher education applicants and to approximate it to the European standards.

KEY WORDS: applicants of higher education; licensed test exam; result of the final attestation.

Рукопис надійшов до редакції 02.09.2020 p.

\section{Відомості про автора:}

Січкоріз Орест Євгенович - кандидат медичних наук, доцент кафедри дитячих інфекційних хвороб, декан фракультету післядипломної освіти Львівського національного медичного університету імені Данила Галицького. 